\title{
Littré e os novos caminhos do positivismo
}

\author{
Littré and the new paths of positivism
}

\author{
ADALMIR LEONIDIO \\ Universidade de São Paulo | USP
}

\begin{abstract}
Resumo Este artigo busca analisar as reelaborações do positivismo, depois da morte de Comte, levadas a efeito por Émile Littré (1801-1881), assim como os caminhos que a doutrina seguiu a partir daí. Tem por base o conjunto da obra do pensador francês, bem como os principais críticos de seu pensamento, tanto aqueles de seu tempo como os contemporâneos. Emprega o chamado método histórico-crítico, que essencialmente busca integrar o conjunto da obra do autor com a totalidade histórica que a envolve e dá sentido.
\end{abstract}

Palavras-chave Émile Littré - positivismo - França - século XIX.

\begin{abstract}
This article seeks to analyse the reworkings of positivisme, after Comte's death, carried out by Émile Littré (1801-1881), as well as the paths that the doctrine followed from there. It is based on the whole of the French thinker's work, as well as the main critics of his thought, both those of his time and contemporaries. The so-called historical-critical method is employed, which essentially seeks to integrate the set of the author's work with the historical totality that surrounds it and gives it meaning.
\end{abstract}

Keywords Émile Littré - Positivism - France - 19th century.

\section{Introdução ${ }^{1}$}

Não existem muitas referências específicas a Émile Littré (1801-1881). Aparentemente a única exceção é Homo Lexicographus: a saga intelectual de Émile Littré na escrita do dicionário da língua francesa, de Jacqueline Nahas e Pedro Fernandes. ${ }^{2}$ Em geral, as referências ao autor aparecem ligadas à história do positivismo. Mas quando a discussão gira em torno da filosofia ou da sociologia, muitas vezes a referência quase exclusiva é Auguste Comte (1798-1857) ou Émile Durkheim (1858-1917). - E se o tema é lateral à história do positivismo, como o republicanismo da Segunda e da Terceira República francesa, seu nome também não costuma aparecer, embora Comte seja citado com certa frequência. 4

E a imensa maioria das obras que fazem referência ao pensamento de Littré na história do positivismo, costuma apresentá-lo como uma consequência da suposta divisão da obra de Comte em duas metades: Littré rompe com 0 mestre a partir do momento em que sua obra toma o caminho religioso e entra em contradição com esta "segunda metade" de seu pensamento. Então Littré é em geral apresentado como um dissidente, que ficou com o cientismo de Comte, mas renegou sua Religião da Humanidade, e com isso criou uma nova escola, o littreísmo. $\underline{5}$

Esta é uma imagem muito pálida e simplista, embora não destituída de certa razão, do que foi o pensamento e a contribuição de Littré para a história do positivismo e do pensamento científico do século XIX. Na verdade, trata-se de uma autoimagem construída pelo próprio Littré e aceita por parte dos contemporâneos, bem como pelos críticos posteriores. Uma imagem mais adequada aos fatos da vida e da obra do pensador deveria dividi-los em duas metades: 
uma primeira em que Littré é absolutamente fiel a todos os princípios formulados por Comte até sua morte, e uma segunda em que ele busca se distanciar e reformular alguns aspectos do comtismo. Mas esta reformulação acabaria por modificar substancialmente o pensamento de Littré, assim como o próprio positivismo, de modo a tornar difícil continuar a defini-lo como positivista, a não ser por uma redefinição do que seja a própria doutrina.

É este percurso intelectual de Littré que buscaremos acompanhar aqui, ressaltando as inflexões mais importantes de seu pensamento, bem como as mudanças introduzidas no positivismo, mas também o que permanece do comtismo e fica como elemento de contradição da autoimagem que Littré buscou construir de si mesmo e de seu pensamento. Pois, de fato, não é sem muitas contradições que Littré buscará se distanciar das questões morais e religiosas colocadas por Comte, guardando apenas os aspectos científicos.

Para proceder a esta análise, primeiramente foi feita uma leitura de toda a obra do autor e em seguida uma esquematização de seu pensamento, dividindo-o em temas ou tópicos mais importantes, depois agrupados de acordo com aquela divisão bipartite de sua obra proposta anteriormente. Na sequência, foi feita uma leitura dos principais comentaristas, inclusive e sobretudo os de sua própria época, a fim de posicioná-los frente àquela divisão. Aqui também foi conveniente dividir os comentários e críticas em temas ou tópicos mais importantes. Por fim, foi feita uma leitura dos livros que tratam do tema e da época, a fim de contextualizar o esquema analítico anteriormente elaborado. A interpretação que se segue é o resultado direto deste trabalho de análise e síntese.

Um dos problemas que apareceu com frequência durante este percurso analítico foi o de saber até onde a imagem que o próprio autor tinha de sua obra e de seu pensamento coincidia com o real significado dela, a partir do trabalho de crítica aqui realizado. Para equacionar este problema, recorreu-se ao método proposto por Lucien Goldmann, segundo o qual é preciso confrontar o significado subjetivo com a significação objetiva de uma obra, a partir da sua relação com as questões históricas mais importantes da época do autor, entendendo que a totalidade da obra é, em certo sentido, uma construção a partir destas questões próprias à época. ${ }^{6}$

0 método expositivo buscou seguir a sequência das obras do autor, bem como das suas mudanças de postura. Às vezes foi conveniente também integrar aspectos da vida do autor, que se mostravam reveladores sobre suas obras e sobre seu pensamento. Por isso, a análise foi dividida em três momentos principais: quando Littré era comtista, ruptura com o comtismo e reavaliação do positivismo (tendências e contradições). Contudo, neste texto, optamos por integrar as duas primeiras partes, de modo que 0 artigo estará dividido em duas seções principais.

\section{De polímata a positivista ortodoxo}

Litrré nasceu em Paris e teve em casa uma educação bastante austera, mas dividida entre o iluminismo republicano do pai e a religiosidade da mãe, fato que de certa forma haveria de marcá-lo por toda sua vida intelectual. 0 pai, um normando de Avranches, fora artilheiro e mais tarde sargento-mor da Marinha francesa. Esteve ligado à Convenção, assim como 0 avô materno, executado pela reação termidoriana. Mesmo sendo de origem humilde, o pai aprendeu várias línguas, como grego e sânscrito, só para contar histórias ao filho. Quando Littré era criança, o pai costumava receber em sua casa, na rue des Maçons, Sorbonne, muitos amigos da época da Primeira República. ${ }^{-}$Mas, apesar de sua educação iluminista, o pai "tinha o mais forte sentimento de repulsa pela zombaria de Voltaire e seus seguidores" às "crenças teológicas".. E isto reflete em parte o respeito que tanto o pai quanto Littré tinham pelas posições da mãe, uma protestante praticante. Então, pode-se dizer que, apesar de ter sido criado em um ambiente laico, aprendeu desde cedo a ter um republicano respeito às opiniões religiosas.

No Liceu Louis-le-Grand era aluno exemplar, ganhando vários prêmios de retórica e sendo destaque em todo tipo de atividade em que se envolvia, mesmo as físicas. Durante este período, aprendeu várias línguas e dedicou-se aos estudos de filologia e literatura. Ao fim do liceu, fez um ano de matemática e chegou a cogitar entrar para a Escola 
Politécnica. Mas um acidente físico o impediu de comparecer aos exames e ele acabou desistindo da ideia. Tornou-se secretário por dois anos do conde Daru e durante esse tempo continuou seus estudos filológicos. Mas desde então, por volta de 1822, começou a estudar medicina. Paralelamente, por cerca de três anos, "ele foi assiduamente ao Jardim Botânico estudar plantas e suas famílias". . Desde cedo, portanto, era notável seu gosto pela erudição.

Em 1827, após a morte do pai, a mãe fica sem meios de subsistência, Littré abandona a faculdade de medicina e passa a lecionar latim e grego para sobreviver. Mas isto não significou o fim de sua relação com a medicina. Embora não tenha se formado, ia todo verão para o campo tratar dos pobres que não tinham acesso a médicos. E era tão respeitado entre eles que chegou a tornar-se membro da Academia de Medicina, mesmo sem ter se formado. Além disso, como veremos, foi responsável por uma das obras mais importantes sobre Hipócrates.

Tudo isso se passa durante os anos da Restauração, que embora não seja uma volta à monarquia absoluta, corresponde a sérias restrições de alguns direitos, como o de voto e de livre opinião. Com Carlos X (que substitui Luís XVIII), a partir de 1824, o regime endurece e institui-se uma aliança entre o Trono e o Altar. Mas o movimento liberal readquire força, com Benjamin Constant, François Guizot e até Chateaubriand, e reivindica, sobretudo, liberdade de expressão.

Após os "três dias gloriosos", em que jornalistas e operários tomaram as ruas de Paris, Adolphe Thiers (1797-1877), um dos fundadores do Le National, juntamente com vários outros republicanos, está convencido de que a República ainda não é uma opção. 0 fracasso de 1792 ainda é uma história viva na memória de todos. ${ }^{10} 0$ nome de Luís Filipe, o duque de Orléans, do ramo mais novo dos Bourbon, passa a ser o nome mais provável para substituir o do neto de Carlos X, Henrique V. Em 31 de julho, ele "aceita receber o título de lieutenant général do reino de uma delegação de deputados, enquanto Carlos $X$ se refugia no castelo de Rambouillet"..11

Por esta época Littré ainda não era o publicista conhecido do Le National, e muito menos o republicano que se tornaria depois, mas ainda assim mantém a tradição paterna e serve como soldado para os populistas durante a Monarquia de Julho e se torna um dos membros da Guarda Nacional que seguiu Carlos $X$ até Rambouillet. No livro Conservation, révolution et positivisme (1879), onde busca reforçar sua autoimagem como republicano, lembra dos acontecimentos da seguinte forma:

No entanto, quando as ordenanças de julho de 1830 se cumpriram, não hesitei em lançar-me na insurreição; uma decisão séria que companheiros da mesma opinião que eu e de caráter muito mais resoluto se abstiveram de tomar. Foi porque eu havia pensado nisso com muita antecedência e tinha assumido firmemente a minha parte. $\frac{12}{2}$

Pouco depois, em 1831, ele foi apresentado a Armand Carrel (1800-1836), editor do Le National juntamente com Thiers, que lhe deu a tarefa de traduzir trechos de jornais em inglês e alemão. Durante três anos permaneceu nesta "posição secundária", segundo Saint-Beuve. Mas, após escrever um artigo sobre o ilustre astrônomo alemão William Herschel, o mesmo com quem Comte manteve calorosas polêmicas sobre o positivismo, esta sua posição mudaria, embora sem nunca se tornar, "a rigor, um colaborador político e uma pena de ação". $\underline{13}$

Por esta época ele retomou os estudos de medicina e contribuiu com vários artigos para um dicionário de medicina, que chegaria a trinta volumes. E é desta época o convite do famoso livreiro Jean-Baptiste Marie Baillière (1797-1885), contra o qual Comte moveria uma verdadeira batalha jurídica, para que Littré escrevesse uma obra sobre Hipócrates. Com conhecimento profundo do grego e habilidades para leitura de manuscritos, juntamente com seus conhecimentos médicos, ele parecia ser a pessoa ideal para esta tarefa. A obra levaria 25 anos para ser concluída (1839-1862), mas é graças ao seu primeiro volume que o nome de Littré começou a ser conhecido: "Só comecei a irromper com o aparecimento do primeiro volume da minha edição de Hipócrates, que me abriu a entrada para a Académie des Inscriptions et Belles-Lettres em 1839". 14

Uma vez na Académie des Inscriptions, ele substituiu Fauriel na Comissão para a História Literária da França (1844). Durante esse tempo, ele publica vários artigos de divulgação científica, tanto no Le National quanto na Revue des Deux 
Mondes. Mas é o trabalho sobre Hipócrates sua grande obra neste momento. Esta aparência de polímata esconde, todavia, um dilema na vida intelectual de Littré, dividida entre a literatura e a ciência. Tensão que só se resolveria com sua conversão ao positivismo, em 1840, quando lê o Cours de philosophie positive e, em seguida, conhece pessoalmente Auguste Comte. Saint-Beuve descreve este encontro como uma espécie de paixão juvenil em que Littré nem mesmo considera as opiniões negativas que se formavam dessa aproximação. Saint-Beuve não cita, mas provavelmente este devia ser o clima no próprio Le National, um jornal de convicções liberais e republicanas que não se harmonizavam bem com a ideia de ordem positivista. De todo modo, isso mostra que as opiniões na imprensa de Paris já não eram muito favoráveis à doutrina de Comte, a quem Saint-Beuve chama de "pensador solitário".

Mesmo assim, graças ao seu prestígio no jornal, Littré conseguiu abrir as portas do Le National para o positivismo: "não que os editores principais fossem adeptos [...] eles tinham filosofias muito diferentes entre si, mas me deixaram lidar com a minha como eu quisesse [...]". .15 Ao longo do ano de 1844 ele publicou vários artigos com o objetivo de resumir as ideias principais de Comte. Estes artigos seriam depois reunidos em um livro, De la philosophie positive (1845). $\frac{16}{}$ E então o Le National acaba por se tornar indiretamente um veículo de divulgação das ideias positivistas: “Desde 1844, tinha neste periódico um ambiente reservado a esta filosofia e uma plataforma aberta para a sua divulgação". Na opinião de Wolf Lepenies, neste momento surge "de um sistema uma escola e de uma doutrina, um movimento". 17. Mas na verdade 0 que Littré está fazendo neste momento é apenas ajudar a divulgar o comtismo.

De fato, o que se nota pelo seu conjunto de textos é que, nesta primeira fase de seu positivismo, Littré está empenhado em tornar o comtismo conhecido e fazer de si mesmo uma caixa de ressonância da doutrina. Este empenho é facilmente perceptível em seu esforço, que se repetiria depois em vários outros textos, de definir "com clareza" 0 que é a filosofia positiva. Ora, Saint-Beuve já havia dito, e isso é fácil comprovar lendo as obras de Comte, e até virou um lugar-comum entre praticamente todos os críticos, que o criador do positivismo tinha um estilo empolado, difícil e cansativo de ler. Littré tinha consciência disso: era preciso traduzir o mestre para que fosse devidamente compreendido e difundido. E de certa forma foi bem sucedido neste sentido, ao menos bem mais do que Comte, pois segundo o crítico Émile Caro, Littré "resume a história do positivismo em sua fase triunfante". 18

Mas é preciso não exagerar muito na expressão. Pierre Larousse, em seu Noveau dictionnaire de la langue française, de 1856, define o positivismo como: "tendência para benefícios materiais e positivos das coisas", 19 uma definição que em nada corresponde às ideias de Comte sobre o positivismo. Mas quando retoma 0 assunto em 1875, já não encontra tanta facilidade em defini-lo e opta por diluir o tema em vinte verbetes, onde resume as ideias principais dos "mais ilustres membros das escolas", tanto inglesa quanto francesa..$\underline{20}$ Ou seja, quando o positivismo realmente se expande fica ainda mais difícil defini-lo como uma escola ou um movimento de ideias.

Esta expansão e esta dificuldade têm de fato um motivo central, como veremos: a divisão da obra de Comte em duas metades conflitantes. Assim, apesar dos esforços "conscientes" de Littré por difundir o positivismo renovado, após a crítica de seu mestre, o que fez objetivamente foi ajudar a dispersá-lo ainda mais. É bem verdade que ajudou a difundir o espírito científico. Mas isso é apenas uma parte do que Comte chamou de positivismo. 0 próprio Comte era muito ambíguo em relação à importância desta difusão da doutrina. Inicialmente desprezou toda e qualquer possibilidade de popularidade. Apenas esperava converter meia dúzia de mentes, a elite intelectual do Ocidente. Só muito depois, convencido de que o positivismo só se tornaria uma doutrina dominante e formaria uma nova sociedade na medida em que conquistasse primeiro as massas operárias, é que passou a dar alguma importância ao tema. E mesmo assim, não esperava ter que fazer muito para isso, pois "estava convencido de que o mundo viria a ele; ele esperou sua próxima hora com a segurança de um homem que se acreditava infalível e ao mesmo tempo universal. Aproximava-se dia a dia esta data marcada por destinos de conversão da humanidade". $\underline{21}$

Mas no que consistia o "positivismo" de Littré antes do rompimento com o mestre? Basicamente em uma expressão vulgarizada do comtismo. Em 1849 Comte já havia proclamado a Religião da Humanidade (1847) e publicado o Discours sur l'ensemble du positivisme (1848), que se tornaria depois a introdução do Système de politique positive, cujo primeiro tomo só veio à lume em 1851. Neste momento Comte está convencido de que é hora de o positivismo entrar em ação, mas como recusa toda ação política direta, resolve criar a Associação Livre para a Instrução Positiva 
do Povo, que se tornará depois a Sociedade Positivista. Juntamente com Fabien Magnin (1810-1884) e Pierre Laffitte (1823-1903), Littré elabora um dos relatórios do grupo, Rapport sur la nature et le plan du gouvernement révolutionnaire de la République française, embora viesse a negar mais tarde a sua autoria. Em seguida, na série de artigos publicados no Le National e depois reunidos no livro Application de la philosophie positive au gouvernement des sociétés et en particulier a la crise actuelle (1850), ele faz profissão de fé: a filosofia positiva já estava criada e era preciso agora aplicá-la na política, criando para isso um novo "poder espiritual". Mas não se pode dizer que ele antecipa o Système, porque praticamente tudo o que diz está contido no Discours de Comte, bem como nos relatórios da Sociedade Positivista. Em suma, ele diz que se aderiu à filosofia positiva, conforme os artigos anteriores, agora deveria aderir à política positiva: "Como não há nada arbitrário aqui, e como é agora uma questão de ciência real, minha adesão aos princípios implicou minha adesão às consequências essenciais". $\underline{22}$

Os artigos foram publicados no Le National, em 1849. E o assunto mais importante neste momento era a Revolução de 1848 e seu significado político, significado que tanto Comte quanto Littré se empenharam por traduzir ao grande público, segundo o ponto de vista da doutrina. Para Littré 1848 significava, antes de tudo, uma mensagem sobre a crise moral em que estava mergulhada a Europa, crise que expunha o predomínio da força e do egoísmo típicos do regime monárquico. Mas, ao mesmo tempo, anunciava o novo que estava por vir, isto é, a paz universal e 0 altruísmo. Nisto iam duas importantes petições de princípio do positivismo de Comte: que a república e o socialismo eram a passagem natural ao positivismo que estava por vir, e que esta revolução, eminentemente intelectual, não pararia nas fronteiras da França.

Ora, por um lado sabe-se que a história da República na França envolve um dilema: trata-se de uma forma de governo transitória em condições revolucionárias, uma espécie de regência, à espera de um regime definitivo, que para muitos era a restauração da monarquia, ou um regime definitivo, escolhido por seus méritos próprios? Embora a República proclamada em 1848 tenha sido o resultado da ação de republicanos convictos da "República pela República", muitos políticos e intelectuais viriam nela apenas uma passagem para alguma outra coisa. $\cdot \underline{2}$ Esta outra coisa para Comte e Littré era o positivismo. Littré estava longe ainda de se tornar o republicano convicto que se tornaria depois.

Por outro lado, sabe-se igualmente que 1848 foi a "primavera dos povos", ainda que a maior parte das repúblicas proclamadas na Europa tenha sofrido um poderoso revés. De fato, segundo Hobsbawm, uma das características comuns a esta "primavera dos povos" em toda a Europa foi sua rápida vitória e sua rápida derrota, "na maioria dos casos, totalmente". Isto quer dizer que as previsões de Comte e Littré a esta altura já haviam sido frustradas de fato. Mas não a sua crença no futuro previsível do positivismo, que continuava inabalável. Outra característica comum explicaria este fracasso: "elas foram revoluções sociais dos trabalhadores pobres". $\underline{24}$

Havia, por esta época, uma convergência quase natural entre socialismo e República. Então, se a república era uma passagem ao positivismo, o socialismo também o era com muito mais razão, na medida em que representava uma tendência ao predomínio do social, em detrimento do puramente individual. Para a grande maioria de republicanos e socialistas, o sufrágio universal era a meta lógica a ser alcançada. E uma vez que os "verdadeiros representantes do povo" chegassem ao poder, o trabalho também teria voz, assim como a riqueza, e seria enfim possível a "harmonização de interesses". $\underline{25}$

Embora Littré concordasse com a ideia de "harmonização de interesses", não acreditava que o sufrágio universal fosse 0 caminho natural para isso. Tão dogmático quanto Comte, defendia que a reforma espiritual deveria anteceder a temporal. Só a ciência poderia garantir o advento do "socialismo positivo": "Não é o estado social que faz a ciência funcionar, é a ciência que faz o estado social funcionar. Essa subordinação é irrefutável". 트 Veremos depois que, na revisão crítica a que submeteu suas próprias ideias, a partir de 1859, ele manterá a ideia de um socialismo científico, mas inverterá as prioridades, pois passará a defender abertamente e contrariamente a Comte, as reformas sociais que poderiam melhorar a sorte dos trabalhadores.

Então, aquilo que para republicanos e socialistas era uma tendência, a convergência para o romantismo e a ideia de educação popular como caminho mais seguro para as transformações sociais, para Littré, tanto quanto Comte, 
aparecia como um princípio doutrinário irrefutável. Para republicanos convictos, a cidadania era o produto elaborado de uma ação política definida, enquanto para positivistas tudo se resumia a uma mudança de postura intelectual diante do mundo. Littré traça a seguir um plano detalhado, com fases e tempo de duração, de uma educação popular positiva, que vai da matemática à moral, segundo a classificação das ciências de Comte. Mas esta educação só seria possível após a criação de um poder espiritual absolutamente autônomo, a quem caberia a direção intelectual e moral da nova sociedade. Nem Comte e nem Littré são republicanos, tampouco socialistas. Não defendem a ação política como condição da sociabilidade e nem a tomada do poder pelas massas, embora admitam reformas para melhorar sua sorte.

Mais tarde, este pensamento de Comte evoluirá para uma adesão explícita ao bonapartismo, que significa uma passagem irrevogável da "fase parlamentar" à "fase ditatorial" da República, a única adequada ao positivismo. Comte estava convencido de que esta fase era definitiva e que representava a última etapa na formação da sociedade positivista. Mas Littré continuará a falar na "ameaça do bonapartismo", embora endosse o autoritarismo de Comte, avesso ao parlamentarismo.

E como era de se esperar de um Littré dogmático, do socialismo ele passa diretamente à Religião da Humanidade, à qual adere sem questionar. Pois pela "lei da filiação histórica", assim como do inorgânico se passa ao orgânico e depois ao social, do indivíduo se passa à família, desta à pátria e por fim à humanidade, que é uma espécie de "pátria universal". E assim se completa a série progressiva que vai da matemática à religião e à moral, bem como do "egoísmo ao altruísmo", uma consequência lógica e ao mesmo tempo natural do progresso científico e social da humanidade.

Aqui Littré ainda não havia reduzido os problemas fundamentais da humanidade aos problemas da ciência. Ao contrário, só tendo a humanidade como ideal, farão sentido na sociedade a moral, a ciência, a arte e a indústria. Em outras palavras, é preciso imbuir a ciência de um propósito, um ideal, que é moral, ético. 0 objetivo da ciência deve ser servir a humanidade. Sem este propósito maior, a ciência não tem sentido na sociedade. E só a filosofia positiva, que não se reduz a uma mera expressão da ciência positiva, pode dar este propósito à ciência e à sociedade.

E aqui surge outro tema caro ao comtismo, o do advento da "paz universal", graças ao fim da guerra entre as classes, tanto quanto entre as nações. Comte e Littré estavam convencidos de que este advento estava profundamente ligado à sorte da república, do socialismo e do positivismo, necessariamente. E não se trata para eles de uma esperança utópica, mas de uma certeza científica, ligada à mesma "lei de filiação histórica" que levaria da república à "federação europeia". Ambos estavam convencidos, portanto, que 1848 anunciava uma nova era de paz para a humanidade: "0 odioso sistema de opressão interna e de espoliação externa que caracterizou os últimos anos do Império não pode permanecer popular por muito tempo". 27

Apesar de ser uma "previsão sociológica", a paz não tinha nada de fatal. Medidas positivas deveriam ser tomadas no sentido de assegurá-la, por meio de uma reforma da Constituição. Entre as mais importantes estão: "plena liberdade intelectual", "para que se forme a verdadeira opinião pública"; "preponderância contínua do poder central", localizado em Paris, "de modo que tendências progressivas se manifestam claramente e a ordem material é vigorosamente mantida"; "limitação do poder parlamentar ao exame do orçamento"; "entrega do poder nas mãos de proletários eminentes, para que as classes superiores, tão obviamente incapazes de liderar as coisas na transição revolucionária, possam ser, no interesse de todos, aliviadas de seu fardo". ${ }^{28}$ Isto é, antes de os chefes das indústrias se tornarem os líderes temporais da era positiva, os proletários assumiriam temporariamente este poder, durante a fase de transição ou socialista. Propõe ainda: "redução do exército", "supressão do orçamento dos serviços religiosos e orçamento da Universidade", que estaria dominada pelos padres, e incentivo ao desenvolvimento do ensino fundamental para as massas. Este ensino deveria ter por base uma "escola renovada", baseada no ensino das ciências fundamentais, aí incluindo obviamente a sociologia e a moral.

Em 1852 é publicado um novo livro de Littré, que contém os dois livros anteriores, de 1845 e 1850, mais uma série de artigos do Le National do ano de 1850 e cujo tema ainda é o socialismo de 1848. Na segunda edição de 1879, quando ele já havia rompido com o comtismo, para cada artigo é anexado um longo comentário, à luz de suas novas posições, basicamente para negar tudo o que havia dito antes. 
Neste livro ele vai argumentar que apesar de a revolução ser essencialmente intelectual, ela vai depender exclusivamente, daqui para frente, das massas, como foi em 1789. É a posição das massas, sua adesão ou não ao positivismo, que vai definir o futuro da França e da Europa. Então tudo se reduz a uma questão de propaganda da doutrina. São as massas "que, tendo se tornado totalmente socialistas, formarão, como sempre, seus líderes à sua imagem". ․ㅡ Mas esta adesão, como dito, só será possível a partir de um árduo trabalho de educação.

Mas alguns obstáculos estariam obstruindo esta ascensão do socialismo e, consequentemente, do positivismo. Aqui ele repete alguns argumentos anteriores, mas curiosamente introduz uma novidade. Esses obstáculos seriam: educação precária, principalmente aquela voltada para as massas, isto é, o ensino fundamental; ausência de liberdade de imprensa; excessivo poder do Parlamento; ameaça de retorno do bonapartismo, "naturalmente guerreiro e aliado da nobreza decadente e do clero"; restrição do sufrágio universal. Explica, então, que embora seja contrário ao sufrágio, acha que ele serve para afirmar o poder das massas durante a transição, "até que as classes altas regeneradas se tornem dignas de dirigir uma democracia igualmente regenerada". ${ }^{30}$ No regime normal, isto é, o do positivismo, uma delegação de poderes deverá então substituir o sufrágio. Quanto à liberdade de imprensa, até por sua experiência no Le National, Littré sabia bem que os operários parisienses conheciam e liam as publicações republicanas, que por esta época já começavam a sofrer a concorrência da imprensa socialista, como La Democratie Pacifique, de Victor Considérant ou mesmo o Le Globe, dos saint-simonianos.

Então, dos três centros possíveis de atração e impulsão do republicanismo e do socialismo, apenas a imprensa merecia a atenção do positivismo. Mas o Le National, que tinha um grande número de leitores, não era um órgão das ideias positivistas. Além disso, por sua moderação política, era muito mais liberal que republicano. Só muito mais tarde, após romper com Comte, é que Littré dará certa importância ao Parlamento e às diferentes associações. Mas isso não se deve apenas ao dogmatismo de Littré. Embora já houvesse um "partido republicano", a Câmara dos Deputados "contava quando muito com meia dúzia de republicanos que nem sequer podiam declarar sua posição, sob pena de sofrerem perseguições". ${ }^{11}$ As sociedades secretas revolucionárias, por sua vez, tinham atuação bastante pálida e as associações políticas pareciam "perfeitamente contidas pela repressão". $\underline{32}$

Mas, afinal, o que era preciso para fazer avançar o socialismo e, consequentemente, chegar ao positivismo? Primeiramente, garantir a paz. Pois à medida que ela se confirmasse nos fatos, mostraria o poder de previsão do positivismo e com isso aumentaria a confiança das massas nele. Daí a necessidade de reduzir os exércitos. Depois, a fusão dos republicanos com os socialistas, tarefa cada vez mais difícil com o crescimento do movimento operário organizado. Mas somente o positivismo representaria a evolução final, que começou com liberalismo após a Revolução, passou pelo republicanismo e chegou ao socialismo: "Desse modo, o positivista inclui o socialista, o socialista inclui 0 republicano, e o republicano inclui o liberal. Esses são termos sucessivamente superiores do mesmo desenvolvimento". E aqui novamente parece muito natural ou lógico para Littré passar do socialismo à Religião da Humanidade: “Chego aqui ao clímax, aquele ponto em que mais importa que minha palavra não falhe em minha tarefa". $\underline{\underline{33}}$

\section{Cientismo e laicismo no novo positivismo de Littré}

Portanto, até a morte de Comte, em 1857, Littré é absolutamente fiel ao comtismo, em todos os seus sentidos. Como dito, o rompimento é, em geral, atribuído ao caminho religioso seguido pela doutrina. Littré teria recusado este caminho, mas teria preservado a parte científica da obra. Mas este argumento é absolutamente contraditório com os fatos: Comte já havia declarado a Religião da Humanidade há mais de dez anos. Além disso, como veremos, foi 0 próprio Littré quem fez esta divisão da obra do mestre em duas metades que se negam.

É bastante sintomático que Littré inicie o livro Paroles de philosophie positive (1859) propondo-se examinar a razão que teria levado a filosofia positiva a "residir em uma obscuridade que a impede entrar, como tantas outras filosofias ou sistemas, em estado de esplendor". $\underline{34}$ Vimos anteriormente como os próprios dicionários tinham dificuldade em 
definir o que era o positivismo. E para ele o mais curioso ainda era que apesar de ninguém saber dizer ao certo o que era o positivismo, os fundamentos da doutrina aparentemente já haviam se apossado "das mentes que refletem, do pensamento que circula, da linguagem que se troca". $\frac{35}{5}$ Então, embora Littré tenha contribuído com o tema do positivismo difuso, a partir da ênfase na "parte científica" da obra de Comte, ele não o inventou, pois já era um sentimento partilhado entre seus contemporâneos. Ademais, foi intenção explícita do autor reformular a doutrina de Comte. Mas não se pode dizer por isso, também, como alguns críticos, que tenha havido algo como um "littreísmo". Os elementos de doutrina são de fato visíveis, mas pouco consistentes, como a busca de conciliação entre elementos sociais e suas convicções republicanas.

Até o último livro, em 1880, este trabalho de revisão e redefinição do positivismo girará em torno de sete temas essenciais: filosofia, religião, método, sociologia, psicologia, economia política e socialismo.

Apesar da insistência na terminologia, Littré está ciente das dificuldades em definir o positivismo como uma "filosofia". Então, por isso, no livro de 1859, em que o rompimento com o mestre é declarado, ele vai defini-lo como uma "concepção de mundo", uma atitude mental, uma disposição diante das coisas do mundo radicalmente incompatível com a religião e a metafísica.

Apesar do conflito entre o positivismo e as filosofias teológica e metafísica, Comte não havia falado em incompatibilidade. Acreditava, ao contrário, que o positivismo representaria uma evolução natural e lógica da teologia e da metafísica. Em Littré o "espírito de negação", particularmente 0 anticlericalismo, que era apenas uma particularidade do comtismo, aparece como uma questão de princípio fundamental e será "decisivo para a popularidade desta escola junto do grande público". $\frac{36}{}$

Uma mentalidade científica e laica, eis a imagem do positivismo que Littré busca construir. De fato, dois temas são centrais na segunda metade do século XIX: a certeza dos homens cultos do período nos caminhos que a ciência estava tomando e 0 avanço incontornável da secularização, ainda que a religião formasse "o idioma no qual a esmagadora maioria da população pensava".. Littré tinha consciência do problema que esta negação sistemática trazia para a própria doutrina, como elemento de contradição implícito. Talvez por isso tenha buscado revitalizar um outro dogma fundamental do comtismo, a crença de que a "era positiva" significaria o fim de todo tipo de discordância.

Mas somente o livro de 1864, Auguste Comte et la philosophie positive, vai marcar com maior clareza esta busca de distanciamento em relação ao comtismo. 0 próprio título já indica isso: Comte é apenas uma parte da história do positivismo, uma história que vem de Turgot e Kant, passa por Condorcet e Saint-Simon, e continua seu curso. Duas coisas são aí essenciais: uma reelaboração crítica da obra de Comte e uma redefinição do positivismo. A reelaboração é para mostrar que Comte desviou, em determinado momento, o curso dessa história e a redefinição para mostrar que o positivismo é diferente do comtismo e não se reduz a ele. Mas, embora Littré evite tocar na ferida, tem plena consciência de que já foi comtista e continua a ser positivista. Então, a operação fundamental é justamente desvincular as duas coisas.

Em outras palavras, era preciso defender o positivismo das críticas feitas ao comtismo. E estas críticas em geral deviam-se aos problemas apontados em sua época no primeiro tomo do Système de politique positive (1851), mormente o seu tom religioso. Desde seus primeiros escritos, Comte sempre defendeu a ideia de uma "política positiva", mas que deveria ser precedida por uma "filosofia positiva". Já no último tomo do Cours de philosophie positive (1842), portanto três anos antes de conhecer Clotilde de Vaux e de proclamar a Religião da Humanidade, ele havia anunciado a segunda parte de sua obra, mas também as perseguições que já vinha sofrendo e que o impediram de dar continuidade a este "grande trabalho"..$\underline{38}$

Tudo pareceu então muito simples a Littré: dividir a obra de Comte em duas metades que se negam, uma do Cours, científica e rigorosa, e outra do Système, religiosa e mística. A primeira representava o autêntico espírito do positivismo, enquanto a segunda era a mera expressão de uma mente transtornada. A única dificuldade nisso seria mostrar que apesar de ter seguido durante muito tempo as ideias alucinadas do mestre, podia falar agora com lucidez em nome daquela primeira parte científica. 
Então, por que não simplesmente negar as ideias de Comte, sem necessariamente dividi-las em duas, como faziam Herbert Spencer e Stuart Mill? Ora, assim como Comte era a evolução natural e lógica de Turgot, Kant, Condorcet e Saint-Simon, Littré se pensava como o elo seguinte da cadeia. Negar as ideias de Comte seria, portanto, negar a própria possibilidade do positivismo. Então era preciso dizer com todas as letras: "Eles não me convenceram; não estou me tornando um discípulo do Sr. Herbert Spencer, continuo discípulo do Sr. Comte". ${ }^{39}$ E em outro lugar: "Eu sou um discípulo da filosofia positiva; Sr. Mill é um crítico". 40 A estratégia é muito clara: elabora sua própria crítica, mas nunca concorda com os críticos de Comte. Assim, afirma-se como o autêntico herdeiro do positivismo, distanciando-se do comtismo, mas igualmente do spencerismo e do empirismo de Mill, que reivindicavam igualmente a chancela do cientismo de seu tempo. Depois da morte de Comte, ele seria a voz oficial do positivismo que retomou seu lugar e segue seu curso.

A questão é saber o quão reelaborado é este positivismo de Littré. A "tarefa é escorregadia", segundo o próprio autor, porque ele não pode se distanciar do comtismo a ponto de fornecer razões aos inimigos do positivismo: "É um momento realmente crítico e do qual não ignorei o perigo; pois parece, ou que, ingrato e tímido, venho a contradizer e diminuir o mestre de quem recebi os ensinamentos, ou que, inconsistentemente, forneço armas ao inimigo que faz guerra às ideias positivas". 11

Após uma cautelosa justificação das críticas ao comtismo, com muitas ambiguidades, Littré passa a analisar aquilo que considera os erros fundamentais do mestre. Primeiramente a questão do método. Segundo ele, na política positiva Comte trocou o método objetivo, passível de comprovação experimental, pelo método subjetivo, apriorístico ou metafísico, onde a imaginação vale mais que as provas experimentais. Aqui, mais do que mostrar os argumentos de Littré, vale enfatizar a imprecisão da crítica.

Sem a intenção de retomar aqui a obra de Comte, a exposição de alguns princípios epistemológicos é, todavia, fundamental. Primeiramente, para ele, o empirismo não passa de uma "estéril acumulação de fatos incoerentes". 42 A formulação de hipóteses é então pré-requisito fundamental, assim como a observação e a experimentação, para 0 conhecimento científico. Sua epistemologia pretende, assim, reconciliar o racional e o experimental. É neste sentido que a "imaginação" aparece como algo fundamental a Comte, na proposição de hipóteses, mas hipóteses que terão de passar pelo teste da realidade.

Depois, para Comte, o sujeito da filosofia não se reduz ao cogito cartesiano. Portanto, o abandono do fundamento absoluto (teológico ou metafísico) deve ser acompanhado pela construção de um novo sujeito, um sujeito coletivo, "rede de relações interindividuais, memória, saber, linguagem" e sentimentos. E é precisamente neste sentido que ele vai falar em unidade objetiva e subjetiva do conhecimento, unidade entre o racional e o emocional. Em nenhum momento em suas obras Comte refere-se a tal substituição do método objetivo da ciência pelo método subjetivo (próprio à religião e à metafísica). Isto é uma interpretação de Littré, interpretação que todos daí por diante aceitaram e passaram a reproduzir. ${ }^{43}$

Da discussão sobre método subjetivo, Littré passa então, como uma espécie de consequência do erro essencial de Comte, a outra discussão muito importante no século XIX, a possibilidade de se combinar lógica e metodologicamente sentimentos e razão. No primeiro volume do Système de politique positive Comte apresenta uma teoria das faculdades cerebrais que pretende ser um passo à frente na frenologia de Franz Gall (1758-1828). Comte julgava e Littré concordava que uma teoria sobre o cérebro era algo fundamental para o avanço da sociologia, pois caso contrário ela ficaria privada de um "vínculo real e preciso entre o cérebro individual e o desenvolvimento coletivo". Mas, segundo Littré, "a descoberta que o Sr. Comte acredita ter feito consiste apenas em uma modificação do sistema de Gall sobre a distribuição do cérebro em faculdades". Além disso, se a própria "concepção de Gall acabou sucumbindo à crítica, implica inevitavelmente que a concepção secundária de M. Comte" $\underline{44}$ também sucumbiria.

As discussões sobre a localização das funções cerebrais remetem ao século XVII, particularmente ao médico inglês Thomas Willis (1621-1675), que foi o primeiro a investigar meticulosamente, por meio da dissecação, a anatomia do cérebro e buscar identificar certas funções, como a memória, a visão e os movimentos com determinadas áreas do cérebro. Gall geralmente ganha destaque nesta discussão por ter desenvolvido a polêmica frenologia, hoje 
considerada uma pseudociência. Deste ponto de vista, o córtex cerebral se divide em 27 "órgãos" separados, cada um deles tendo uma função distinta. 0 tamanho de cada "órgão" se relaciona com o desenvolvimento no indivíduo de uma faculdade correspondente. Quando crescem, estes órgãos pressionam o crânio, formando protuberâncias externas que 0 frenologista consegue observar e medir. Assim, existiria uma correspondência estreita entre o tamanho e o formato do crânio e 0 caráter dos indivíduos. $\underline{45}$

Quando a doutrina de Gall apareceu, ela despertou grande simpatia e acalorado debate entre fisiologistas. A revista Edinburgh Review, em 1815, chamou a frenologia de "charlatanismo", mas após os comentários críticos de Johann Spurzheim, famoso fisiologista seguidor de Gall, a doutrina conquistou muitos convertidos em Edimburgo, como o conhecido jurista George Combe, que escreveu o livro Constituição do homem. A frenologia fez tanto sucesso que alguns patrões passaram a adotá-la como método seletivo de seus funcionários. E embora os avanços da neurologia tenham diminuído consideravelmente este sucesso, ela levou muito tempo para perder por completo sua credibilidade. A Sociedade Frenológica Britânica, por exemplo, só seria fechada em 1967. Isso porque apesar de seus exageros, algumas das ideias da frenologia permanecem até hoje como legado da neurologia como, por exemplo, a localização de algumas habilidades no cérebro e a ideia de que o uso repetido pode fazer certas partes do cérebro crescerem. $\underline{46}$

Mas Littré recusa a frenologia de Gall por motivos bem mais dogmáticos do que a maioria da crítica de sua época. Segundo ele, o grande problema da frenologia devia-se ao seu método apriorístico. Nada do que afirmava Gall era passível de prova. Então, embora em tese concordasse com a ideia de localização das funções cerebrais, ela não podia ser comprovada no estágio em que a ciência se encontrava.

Este método apriorístico é, no entanto, apenas um aspecto da crítica de Littré à "teoria cerebral" do mestre. A crítica mais importante diz respeito à "afirmação sem provas", por parte de Comte, de que o número de órgãos responsáveis por funções afetivas e morais excediam "grandemente em número, volume e intensidade as faculdades e órgãos atribuídos à inteligência", ${ }^{47}$ isto é, que a mente está subordinada ao coração. Também neste ponto Littré aproveita para criticar a "teoria da alma" de Comte, porque estaria voltando às ideias animistas da Idade Média, introduzindo "ficticiamente no mundo a vontade que encontrou na alma humana".

Os dois aspectos da crítica estão na verdade relacionados e são o núcleo duro das supostas posições teológicas de Comte. Trata-se de uma discussão bastante antiga entre aqueles que se dedicaram ao estudo do cérebro e da relação entre razão e sentimentos. Demócrito de Abdera atribuía a três órgãos diferentes as funções que hoje atribuímos ao cérebro: enquanto a consciência e o pensamento estavam ligados ao cérebro, as emoções e desejos estariam ligados ao coração e ao fígado. Aristóteles, por seu lado, estava convencido de que o coração era o centro de comando do corpo, enquanto o cérebro servia somente como uma espécie de "câmara resfriadora". Além disso, tanto Aristóteles quanto Galeno acreditavam num "pneuma vital" ou alma que tinha ligação com vários órgãos do corpo. Em suma, desde os antigos acreditava-se que os humanos eram formados por "substâncias corpóreas e não corpóreas" e que determinados órgãos estavam no controle da vida. Além disso, acreditavam haver uma diferença essencial entre os vivos e não vivos.

Aristóteles recusava a ideia de que corpo e alma eram entes separados, mas aceitava a ideia de que o pneuma ou alma era o responsável pelo pensamento tanto quanto pelos sentimentos e a ação. 0 cristianismo iria depois monopolizar o tema da alma e condenar toda discussão que buscava saber onde ela estava localizada. No século XVII, René Descartes (1596-1650) iria defender o modelo do corpo máquina, regido por leis precisas e regulares. As atividades mentais e físicas não seriam, portanto, regidas por nenhum tipo de alma. Mas defendeu a existência de um res cogitans imaterial responsável pelas atividades puramente mentais, assim como a ideia de que a glândula pineal era a residência desta "alma". .50

Mas, à medida que avançavam os estudos fisiológicos do sistema nervoso, particularmente a partir do século XIX, diminuía a importância atribuída à alma. Neste período, a nascente psicologia quase se confundia com os estudos de fisiologia cerebral. E essa parece ser, inicialmente, a posição de Littré, a partir da qual busca criticar as posições da frenologia de Comte. Embora trate do tema em ao menos dois artigos em 1867, ele apenas reproduz ou divulga as 
posições predominantes no século XIX: "A constituição material da substância nervosa é o ponto de junção entre 0 espírito humano e as leis ou fatos gerais. Se eu fosse mais jovem, eu me empenharia neste trabalho". .51

Pouco depois ele vai retomar estas discussões, não para criticar Comte, mas para defendê-lo, mais uma vez, das críticas de Mill. Segundo o filósofo inglês, Comte cometeu quatro erros ao tratar da psicologia: ter tornado a psicologia parte da biologia; não ter admitido a psicologia na série das ciências; ter tornado imperfeita a constituição da sociologia, não fazendo com que a psicologia nela interviesse; não para fornecer o critério lógico da verdade.

De fato, a posição de Comte em relação à psicologia é bastante ortodoxa e espelha uma visão comum à ciência de seu tempo: não pode haver ciência daquilo que não se pode observar. Daí por que ele resumiu os problemas da psicologia aos problemas da fisiologia cerebral. Mas neste preciso momento, buscando salvar o positivismo sem entrar em grandes contradições, Littré introduz a ideia de dividir os estudos de psicologia em dois ramos distintos e separados: 0 das "faculdades cerebrais" ou "intelectuais e afetivas" e o dos "produtos dessas faculdades", isto é, do cérebro e suas funções e das manifestações psíquicas do cérebro. Do primeiro ponto de vista ele estaria ao lado de Comte e do segundo ao lado de Mill. $\underline{52}$

Nesse ponto, Littré como Comte seguiam uma tendência da neurociência de seu tempo, herdeira das posições de Descartes, de separação entre mente e corpo, entre os estudos neurofisiológicos e psicológicos, entre razão e emoções..$\underline{53} E$, uma vez separados, estes dois ramos de estudo pareciam disputar a primazia: quem estaria no comando, afinal, a mente ou o coração? Mas neste ponto é preciso ressaltar certa distância de Littré em relação ao mestre, porque enquanto Littré manteve-se fiel aos pressupostos frenológicos, Comte buscou deles distanciar-se ao propor a ideia de unidade entre o racional e o emocional no livro de 1848, como vimos.

Este debate remete então a uma outra discussão que teve enorme importância no século XIX. De fato, a questão incômoda que fica é saber por que Littré, apesar de no fundo concordar com as críticas de Mill às posições de Comte em relação à psicologia, insiste que elas não comprometem a sociologia e a filosofia criadas pelo mestre?

Ora, conforme mostrou Wolf Lepenies, no século XIX a literatura e a sociologia disputavam a primazia de fornecer a orientação-chave da civilização moderna, o direito de ser a doutrina de vida apropriada à sociedade industrial. Essa competição revela um dilema da sociologia: "a hesitação entre uma orientação cientificista, pronta a imitar as ciências naturais, e uma atitude hermenêutica, que aproxima a disciplina da literatura" ${ }^{54}$ Ela é acentuada ideologicamente pela contraposição entre razão e sentimentos, llustração e Contra-llustração.

Littré sempre esteve dividido entre seus trabalhos de médico, filólogo e historiador da literatura, até encontrar sua expressão sintética no positivismo de Comte. Agora esta síntese via-se abalada não só pelo cisma com o comtismo, mas também pelo surgimento de uma nova tensão entre positivismo e psicologia. As críticas a Mill refletem em parte esta tensão, pois segundo elas a "nova escola" do filósofo inglês estava "em toda parte e em constante ascensão". $\underline{55}$

Mas a medida do sucesso da filosofia para Littré era a sociologia positiva, para a qual, como dito, a psicologia tinha pouco a oferecer. Então, logo a seguir à discussão sobre este tema, no livro de 1864, Littré vai concentrar-se na questão da economia política. Primeiramente, busca distanciar-se das posições que outrora defendera em relação ao socialismo e às possibilidades da paz perpétua. Em 1867, no artigo já referido de La Philosophie Positive, em que busca responder às críticas de Mill a Comte, ele volta ao tema, mas também pouco acrescenta. Para Mill, o maior indicador da insuficiência da sociologia de Comte é ter deixado de fora a economia política. Mas embora Littré reconheça essa insuficiência, não acha que ela era fundamental para a criação da sociologia, pois era apenas "uma parte do estado estático", e o próprio estado estático seria, das duas partes da sociologia, a menos importante. As "bases para a constituição da ciência (sociologia), se encontram no estado dinâmico". $\underline{56}$ Obviamente aqui também se trata de uma interpretação de Littré, pois em nenhum lugar Comte deu primazia à dinâmica social, buscando sempre uma harmonia entre ordem e progresso.

Mas, de tudo isso, não fica em momento algum muito claro quais são, afinal, as novas posições de Littré. Que imagem do positivismo e da sociologia ele quer construir depois da morte de Comte? No fim do texto de 1864 esta 
posição começa a se desenhar em torno de certa convergência entre republicanismo e socialismo.$^{57} 0$ tema passou a ser uma das preocupações centrais do positivismo de Littré e será retomado pouco depois nas páginas da recém-criada revista La Philosophie Positive em um artigo intitulado La politique. Neste artigo ele faz questão de destacar que não fala em seu próprio nome, mas sim em nome do positivismo. Mas a despeito do ar de novidade, a abordagem é ainda bastante comteana. Recusa o nacionalismo, por ser a origem de todas as guerras, e embora não fale em federação europeia, como Comte, acredita que somente a formação de algum tipo de jurisdição internacional, que coloque os interesses da Europa acima dos interesses nacionais, permitirá a conquista definitiva da paz. Compara as sociedades com a família, onde é preciso subordinar os interesses de uns aos interesses de todos. Não arrisca mais nenhuma previsão, mas acredita no futuro de uma política europeia para a paz.

Mas, ao avançar na discussão e tomar o exemplo da Alemanha, que insistiria em uma posição belicosa, aprofunda-se mais sua visão republicana. Segundo ele, a liberdade e a paz na Alemanha só seriam possíveis quando a "voz popular" fosse ouvida "no que diz respeito a tão graves problemas"..$\underline{58} 0$ exemplo é o self-government inglês, que cumpriria três funções principais: manter a preocupação permanente com a coisa pública; subordinar a vontade de cada um à vontade de todos, banindo toda forma de despotismo; o único império aceitável pelos cidadãos é o da lei. E acrescenta por fim, que ao contrário dos liberais, republicanos e socialistas têm na liberdade apenas um meio e não um fim em si mesmo. Por isso, aceita as críticas de Mill ao autoritarismo de Comte, mas busca conciliar o positivismo deste com o liberalismo daquele. Assim, continua rejeitando o "axioma metafísico" da "soberania do povo", mas defende a "participação direta dos governados em seu próprio governo".$\underline{59}$

Mas, na tipologia que elabora dos socialismos, a posição é praticamente a mesma da época dos artigos do Le National. Segundo ele, existem "dois socialismos", "um metafísico e outro positivo". 0 socialismo metafísico seria aquele que, sem se basear na história e na sociologia, "projeta algum sistema que ele supõe capaz de remediar os males assinalados". Este seria o caso, por exemplo, daqueles que defendem a "comunidade de bens", a "igualdade de salários", o "Estado mestre de tudo". Estas posições seriam incompatíveis com a ordem natural e a ordem social do mundo. 0 socialismo positivo, por seu lado, defende o estabelecimento de cooperativas, a regularização das greves e a "unidade internacional dos interesses dos trabalhadores". mistura várias tendências, do socialismo utópico ao socialismo de Estado de Lassalle.

Littré não é socialista, obviamente, embora haja certa aproximação entre seu republicanismo e certos temas sociais da época, como dito. Mas a aproximação entre positivismo e socialismo era um fato da época. Esta aproximação se dava de duas maneiras. Primeiramente, pelo tema difuso do cientismo. De fato, sabemos da admiração de Marx por Darwin, assim como da oposição feita por Engels entre o socialismo científico, que era o seu, e o socialismo utópico dos anos 1840. Contudo, Marx foi muito enfático ao ser perguntado pelo jornal The World, de Nova lorque, se havia no socialismo elementos de positivismo: “De forma alguma. Há entre nós positivistas, como também há positivistas que não pertencem à nossa organização, embora ativos. Porém, isso não é de forma alguma mérito da filosofia que professam, a qual não tem nada em comum com as ideias do poder popular tal como nós o entendemos; a sua filosofia limita-se a querer substituir a velha hierarquia por outra nova". 11

Depois, a aproximação entre positivismo e socialismo se dava também por meio do comtismo militante de Pierre

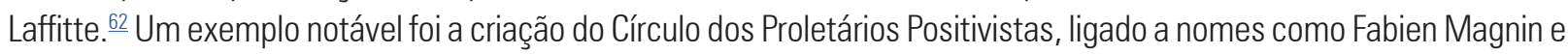
Gabriel Mollin, delegados no Congresso de Basileia da Associação Internacional dos Trabalhadores de 1869. Mas sabe-se também que 0 avanço do socialismo reformista coincidiu com o avanço do positivismo da II Internacional, de nomes como Bernstein e Kautsky. $\stackrel{63}{ }$ Ponto de vista este que de certa forma coincide com o republicanismo de Littré. Este vai lamentar, por isso, que, ao contrário da Inglaterra e da Alemanha, onde o movimento socialista estaria evoluindo para o reformismo, os franceses ainda mantivessem sua tradição revolucionária. Mas a nota final do artigo parece dar razão à crítica de Marx e até endossar o tom utópico de Comte: "A filosofia positiva mostra que o fim do desenvolvimento social é um ideal humano onde encontramos as leis naturais como uma regra salutar, a humanidade como um gênio beneficente e a história como uma consagração piedosa". .64 
0 problema do ideal no positivismo seria recolocado em inúmeras ocasiões. Mas suas posições sofreriam uma nova guinada, mais republicana que socialista, a partir do advento da Terceira República, em particular depois dos eventos da Comuna de Paris. Como senador, conclama os franceses a fortalecerem as bases da República frente aos monarquistas, que ainda eram uma ameaça à estabilidade e à paz na França. $\underline{65}$

Littré se encontra aqui a uma distância considerável da sociologia de Comte, ligada a esquemas rígidos de previsão e ordem. No fim, então, Littré acaba por dar razão a Mill pois, segundo ele, embora Comte tenha criado as bases da "ciência nova", passou daí à sua aplicação na política, sem chegar a escrever um "tratado de sociologia" que servisse de modelo para a compreensão dos "fatos sociais". Comte teria deixado de lado a tarefa de descrever a sociedade e focado suas atenções em como organizá-la e normatizá-la. Mas embora Littré tenha razão nesta crítica, é preciso acrescentar que este era precisamente o projeto de Comte. Mas também é preciso acrescentar que apenas Durkheim daria o passo à frente. Littré em nada contribuiu para o avanço da sociologia criada por Comte. Estava ocupado demais com a militância da causa republicana.

Neste ponto, também é notável sua mudança em relação às perspectivas da paz na Europa e no mundo: “Por muito tempo, só podemos ser espectadores da política europeia, mas uma coisa só nos diz respeito: a nossa reorganização política, financeira e militar" $\underline{66}$ Palavras curiosas para um pacifista. Em outro artigo da revista La Philosophie Positive, de 1878, ele vai falar então da "paz provável" e da "paz possível", e não mais da "paz prevista". 67

A esta altura Littré não tem mais certeza nem mesmo da existência da filosofia positiva como uma escola ou como um movimento de ideias: "É uma questão de saber se a filosofia positiva veio ou está por vir". $\underline{\text {. }}$ Mas em seu penúltimo livro, de 1879, ele não será tão dúbio: fará uma sistemática revisão do livro de 1859, renegando ponto por ponto todas as afirmações e "crenças infundadas" ali contidas. Mas é de se perguntar por que afinal não fez isso antes? Por que só agora?

Primeiramente, Littré estava velho e doente, e é nesta altura da vida que se costuma perguntar "o que é isto, afinal, que fiz toda a minha vida?". Mas no fim do século XIX, a despeito do avanço da democratização e da secularização, que fará florescer enfim a velha crença burguesa na ciência, na razão e no progresso, algo começa a mudar no campo científico: as certezas começam a ser questionadas em várias áreas do saber. Ernest Renan (1823-1892), por exemplo, escreverá um livro bastante pessimista sobre La reforme intellectuele et morale de la France (1871) e se perguntará sobre 0 que terá o futuro de certo e inevitável, afinal. .99

Mas, sem dúvida, esta revisão sistemática de sua obra tem a ver igualmente com uma outra característica muito importante do intelectual Littré: ele acredita que com um lance de boa vontade seria possível corrigir seus erros e aceder à verdade. Lembra por isso aquele "princípio do Barão de Münchhausen" descrito por Hans Albert e depois por Michael Löwy para definir a postura epistemológica do positivismo. ${ }^{70}$ "Não foi de boa vontade que me resignei a imprimir essas páginas estranhas", $\underline{71}$ diz ele sobre o relatório escrito com Laffitte.

Mas, em 1879, ele estava convencido também de algo bem mais radical: "as condições inerentes ao ambiente político e social da França tornavam as concepções de Comte uma hipótese irrealizável". $\underline{72}$ A que condições se refere exatamente? Primeiramente, os fatos após 1848 haviam mostrado o quão problemática era a República no contexto francês e que dificilmente se poderia creditar a ela uma fase de transição ao regime positivo da Humanidade, bem como se poderia acreditar que o modelo francês poderia ser exportado para as demais nações europeias, que tinham sua própria história e seus próprios problemas. Depois, como havia mostrado 1848 e mais ainda 1871, "os proletários não estavam em posição de tomar e manter o poder". Os proletários, de fato, não seriam o conjunto das classes populares, ao menos na França, onde outra parte muito importante e mais numerosa era composta pelos camponeses. Por fim, 0 movimento socialista, à medida que se organizava a classe operária em sindicatos e partidos, não mostrava nenhuma tendência de se converter ao positivismo, apesar de haver socialistas positivistas e vice-versa, como havia dito Marx.

Uma vez convencido de que o proletariado não tinha um papel privilegiado na história da França como supunha Comte e de que todos os governos que surgiram sob clamor popular resultaram em "anarquia ou ditaduras", ele acabou 
optando pelo "regime parlamentar puro e simples". Bon e Gabriel Tarde sobre psicologia das multidões. 0 próprio fenômeno das multidões era algo recente. Mas nota-se certa evolução do pensamento de Littré neste sentido: a multidão, "muito apta a fazer prevalecer sentimentos e tendências, a apoiar e sancionar, não é assim para governar". Quanto mais numerosa a multidão, menos capaz parecia "de tomar decisões em questões de governo". "As luzes são insuficientes", "as ocupações privadas tomam todo seu tempo" e "os interesses se chocam sem acordo". As massas são irracionais. Este é o novo consenso em torno do positivismo ressignificado de Littré. 0 regime parlamentar era, portanto, o mais racional e adequado para a Europa neste contexto: "dá garantias suficientes à ordem", "dá também liberdade, porque inclui uma imprensa livre de obstáculos", permite "a participação, por representação, dos grandes números na gestão de assuntos públicos" e, finalmente, "está aberto a reformas indicadas pela experiência política e pelo progresso geral". Littré passa então de republicano convicto a "republicano parlamentar". $\underline{74}$

Afasta-se assim, cada vez mais, de qualquer ideia possível de revolução. Segundo Caro, Littré devotou profundo "ódio contra o socialismo armado" de 1871. E sob este ponto de vista, tratou como crime político qualquer insurreição, bem como qualquer golpe de estado que derrubasse ou tentasse derrubar um poder estabelecido, a fim de colocar de volta nas mãos de um homem ou de um partido a gestão dos assuntos públicos. $\frac{75}{}$ Mas nisso não estava, obviamente, sozinho. Muitos socialistas, alguns diretamente envolvidos com os acontecimentos de 1848, rejeitaram a Comuna: Maxime Du Camp, Louis Blanc, Théophile Gautier, Leconte de Lisle, Jules Simon, Renan, Goncourt, Louis Veuillot, Francisque Sarcey, Alexandre Dumas Filho, George Sand, Taine, Littré, $\underline{76}$ Bourguet, Flaubert... ${ }^{77}$

A esta altura um Flaubert é mais positivista que Littré. Irritado com as tropas prussianas que ocupavam algumas regiões da França e impediam o Exército de Versalhes de chegar a Paris, mas também com os communards e com 0 perigo da reação clerical e monárquica que se esboçava para ele, o romancista argumenta que a política deveria ser obra da ciência. E citando o próprio Littré, defende um "governo de mandarins", da "legítima aristocracia", a do espírito.78

Mas o mais curioso é que os communards conseguiram avanços, sonhados tanto pelo Littré comtista quanto pelo dissidente, que até então nenhum republicano havia conseguido. A $1^{\circ}$ de abril de 1871 decidiram que 0 salário mais alto de um funcionário da Comuna não podia exceder 6 mil francos. No dia seguinte, decretaram a separação entre a Igreja e o Estado, bem como a supressão de todas as subvenções do Estado para fins religiosos, declarando propriedade nacional todos os bens da Igreja. Deveriam ser retirados das escolas todos os símbolos religiosos, assim também tudo o que estivesse "na órbita da consciência individual". $\underline{79}$

Este ponto de vista laicizante da esfera pública, segundo o qual toda religião não era senão um problema de foro íntimo, também era o ponto de vista de Littré. Durante uma sessão do Senado, enquanto era legislador, posicionou-se contra "poderes que the pareciam carecer de liberalismo e tolerância", pois considerava seu dever político mais estrito assegurar que as teologias gozassem da proteção e independência que o Estado deve a todas as doutrinas. Este foi 0 assunto especial de um texto, publicado quase simultaneamente na Revue de Philosophie Positive e no jornal liberal Le Temps, em 1879, sob o título "Le catholicisme au suffrage universel en France", que teve um grande impacto na opinião pública. Sem deixar de combater o clericalismo, defendia um liberal respeito a todas manifestações religiosas. E é no mesmo sentido que vai defender a plena liberdade de ensino, inclusive da própria Igreja: “0 que! Dizem-nos: devemos, portanto, conceder tolerância àqueles que não toleram? Devemos conceder liberdade àqueles que a recusam aos outros? Sr. Littré não hesita em dizer: Sim". .00

Em suma, o positivismo ressignificado de Littré tem muito mais de republicano que de socialista, afastando-se cada vez dos temas sociais e fazendo coro com a ideologia oficial burguesa segundo a qual a raiz da pobreza está na ignorância. Mas também tem muito pouco do liberalismo de Mill. De fato, para o republicanismo francês a liberdade não é uma condição natural do homem, "mas o resultado de uma vontade política ativa". E, do mesmo modo, diferentemente de outros países, a política é a condição da sociabilidade, assim como da identidade cultural do povo francês. Ao contrário dos liberais, os republicanos fazem da liberdade política "não a garantia das liberdades individuais, mas 0 fundamento de um novo estado social". .11 
Em sendo assim, para os republicanos "é a educação e não o nascimento que cria a identidade dos cidadãos", pois a vontade política não emana de vontades individuais, mas de "pessoas razoáveis", isto é, "consciências emancipadas", capazes de independência em relação aos usos e às crenças predominantes na sociedade. Cidadão não é o homem em abstrato, nem o indivíduo natural, mas o indivíduo instruído, "consequência mais que a causa da instituição política". 82

Obviamente, como mostrou Mona Ozouf, esta era a autoimagem que os republicanos franceses queriam passar de si mesmos e da nação que começavam a construir. Por isso mesmo é que vai haver uma profunda identidade entre a luta pela república e pela escola laica. E o contraponto óbvio é a identificação similar que os ultramontanos faziam entre restauração monárquica e ensino católico. $\frac{\underline{83}}{E}$ dada a centralidade da "questão escolar" para o conflito político entre monarquistas e republicanos, ela acaba por submergir todas as outras questões da época, algumas delas centrais para positivistas históricos, como a separação entre Igreja e Estado.

De certa forma, Littré apostou, no fim da vida, que só a luta republicana daria razão ao positivismo, particularmente a luta pela completa secularização do Estado: "O Sr. Littré havia entendido bem as vantagens disso, o que esta ardente controvérsia deveria dar à doutrina que representava". $\underline{.4} \mathrm{E}$, se não apoiou a luta dos communards, foi, por um lado, por uma óbvia questão de classe, mas, por outro, como dito, por uma questão de princípio, pois era contra toda ação violenta ou revolucionária. Além disso, após o Tratado de Frankfurt e a definição política do novo regime, com uma grande maioria monarquista na Assembleia, intensificam-se as perseguições aos republicanos e o país torna-se palco de intensas demonstrações católicas e ultramontanas. Em suma, o inimigo encarniçado da República para ele é o "Partido Católico" $\underline{\text { " } 5}$ (mas não os católicos).

Deste ponto de vista, dificilmente se pode chamar de positivista o último livro de Littré sobre a Terceira República (1880). Então, a questão que se coloca a esta altura é "o que sobra do positivismo, afinal?". Ainda no livro de 1879 ele disse: "A hierarquia das ciências me convence; a sociologia me mostra algumas coisas grandes e a filosofia que resulta dessa coordenação do conhecimento humano não deixa mais liberdade hoje do que então para recusar meu consentimento. Isso é tudo". Ou nada, porque a hierarquia das ciências nem é uma originalidade de Comte, como também concorreu com inúmeras outras, inclusive a do próprio Littré, que a ela acrescentou a economia política e a psicologia, como vimos. A sociologia, por seu lado, foi despojada daquilo que havia de mais essencial para Comte, a sua capacidade de fazer prognósticos. Por fim, a filosofia positiva reduziu-se a sua pura expressão negacionista: nega toda forma de manifestação teológica e metafísica, mas também todo materialismo e todo ateísmo, toda causa e finalidade no mundo, tudo o que não possa ser observado e submetido a leis naturais, enfim, tudo o que não comporte a medida das ciências da natureza. "Essa concepção é o último resíduo positivista de seu pensamento; é também a conclusão real de todo o movimento positivista, a última unidade remanescente entre os diferentes grupos de pensadores que, em algum grau, afirmam ser positivistas". .6

\section{Considerações finais}

Ao analisar o conjunto da obra de Littré, percebe-se haver uma lenta evolução de seu pensamento, que de comtista ortodoxo passa a uma profunda revisão da obra do mestre. Desta revisão sobra bem pouco, mormente o cientismo e 0 anticlericalismo. Em relação às questões sociais, basicamente reproduz as posições reformistas do republicanismo de seu tempo. Mas diferentemente de Laffitte, nunca aceitou qualquer aproximação com o movimento organizado da classe operária, nem mesmo quando era ortodoxo e aceitava as posições de seu mestre em relação ao socialismo.

Como podemos, então, sintetizar a situação do positivismo, a partir das questões apresentadas na obra de Littré, no fim do século XIX? Por um lado, temos os fiéis seguidores que acompanharam Auguste Comte até o fim, como 0 Dr. Robinet e M. Laffitte, e, por outro lado, aqueles que acompanharam M. Littré em suas reformulações e ressignificações do positivismo, como o russo M. Wyrouboff e o Dr. Charles Robin. 0 grupo de Laffite tem em Paris, segundo Émile Cora, "algumas centenas de membros, no máximo", mais "alguns grupos" existentes em algumas províncias. 
Haveria também alguns poucos fiéis fora da França, particularmente na Suécia e em partes do sul da Alemanha. Na Inglaterra, observa-se a mesma tendência que na França: por um lado os comtistas como Harriet Martineau, Richard Congrève e o Dr. Bridges, que manteve viva polêmica com Mill pela divisão feita, como Littré, da obra de Comte em duas metades que se negam. Ao lado de Mill, mas com diferenças significativas, pode-se colocar também Spencer, que buscou ressignificar o positivismo de Auguste Comte.

Ao lado desses "positivistas de primeira ou segunda hora",, 7 na França e na Inglaterra, devemos marcar o lugar de uma multidão flutuante e sempre crescente de positivistas por intenção e de fato, homens de ciência, políticos, homens do mundo, como Gambetta e Ferry, que, sem ter estudado profundamente a doutrina, se apegaram a essas duas proposições que compreenderam claramente através das complicações e obscuridades dos detalhes e nas quais, aliás, se resume a filosofia da escola: excluir a metafísica e a religião e reduzir o conhecimento à ciência positiva, que deve bastar para tudo, sendo a única que pode dar resultados verificáveis e estar fora de possíveis erros e contradições. Trata-se daquilo que ficou conhecido entre historiadores por positivismo difuso ou cientismo, para o qual a contribuição de Littré foi sem dúvida decisiva.

\section{Notas e referências bibliográficas}

Adalmir Leonídio é professor da USP/Esalq. E-mail: leonidio@usp.br

1 Pesquisa financiada pela Fundação de Amparo à Pesquisa do Estado de São Paulo (Fapesp).

2 NAHAS, Jacqueline; FERNANDES, Pedro. Homo lexicographus: a saga intelectual de Émile Littré na escrita do dicionário da língua francesa. Foz do Iguaçu: Editares, 2017.

VERDENAL, René. A filosofia positiva de Auguste Comte. In: CHATÊLET, François. História da filosofia, v. 5. Rio de Janeiro: Zahar, 1987; LÖWY, Michael. As aventuras de Karl Marx contra o barão de Münchhausen. São Paulo: Busca Vida, 1987; LEPENIES, Wolf. As três filosofias. São Paulo: Edusp, 1996.

GRANGE, Juliette. L'idée de République. Paris: Pocket, 2008; AGULHON, Maurice. 1848: o aprendizado da república. Rio de Janeiro: Paz e Terra, 1991.

RIBEIRO JR., João. 0 que é positivismo. São Paulo: Brasiliense, 1983; GRANGE, op. cit.; LEPENIES, op. cit.; WINOCK, Michel. As vozes da liberdade. Rio de Janeiro: Bertrand, 2006

6 GOLDMANN, Lucien. Dialética e cultura. Rio de Janeiro: Paz e Terra, 1967.

7 SAINT-BEUVE, Charles A. Sur E. Littré: sa vie et ses travaux. Paris: Hachette, 1863.

8 CARO, Émile. Littré et le positivisme. Paris: Hachette, 1883. p. 13.

9 SAINT-BEUVE, op. cit., p. 25.

10 HOBSBAWM, Eric. J. A era do capital. Rio de Janeiro: Paz e Terra, 1996.

11 WINOCK, op. cit., p. 165.

12 LITTRÉ, Émile. Conservation, Révolution et positivisme. Paris: Hachette, 1879. p. 79.

13 SAINT-BEUVE, op.cit., p. 30.

14 LITTRÉ, op. cit., p. 38.

15 LITTRÉ, op. cit., p. 10.

16 LITTRÉ, E. De la philosophie positive. Paris: Ladrange, 1845.

17 LEPENIES, op. cit., p. 31.

18 CARO, op. ct., p. 2

19 LAROUSSE, P. Noveau dictionnaire de la langue française. 14ème èd. Paris: Larousse et Boyer, 1863. p. 345.

20 LAROUSSE, P. 1874, p. 1494-1498.

21 CARO, op. cit., p. 60.

22 LITTRÉ, E. Application de la philosophie positive au gouvernement des sociétés et en paarticulier a la crise actuelle. Paris: Ladrange, 1850. p. 2.

23 AGULHON, op. cit., p. 9-10.

24 HOBSBAWM, op. cit., p. 33-35.

25 AGULHON, op. cit., p. 22.

26 LITTRÉ, 1850, op. cit., p. 40.

27 LITTRÉ, 1850, op. cit., p. 42.

28 LITTRÉ, 1850, op. cit., p. 105.

29 LITTRÉ, E. Conservation, révolution et positivisme. Paris: Ladrange, 1852. p. 120. 
LITTRÉ, op. cit., p. 125.

AGULHON, op. cit., p. 24.

AGULHON, op. cit., p. 28.

LITTRÉ, 1852, op. cit., p. 200 e 230.

LITTRÉ, E. Paroles de philosophie positive. Paris: Ladrange, 1859. p. 1.

Idem, p. 2.

CARO, op. cit., p. 75.

HOBSBAWM, op. cit., p. 375.

COMTE, A. Discours sur l'ensemble du positivisme. Paris: Mathias, 1848. p. 1.

LITTRÉ, E. Auguste Comte et la philosophie positive. Paris: Hachette, 1864. p. 301.

LITTRÉ, E. Auguste Comte et Stuart Mill. Paris: Germer Baillière, 1867a. p. 3.

LITTRÉ, 1864, op. cit., p. 480.

COMTE, op. cit., p. 25

Ver, por exemplo: GRANGE, op. cit.; RIBEIRO JR., op. cit.

LITTRÉ, 1864, op. cit., p. 500-501.

ROONEY, Anne. A história da neurociência. São Paulo: M. Books, 2018. p. 48-53.

ROONEY, op. cit., p. 54-56.

LITTRÉ, 1864, op. cit., p. 540.

LITTRÉ, op. cit., p. 541.

ROONEY, op. cit., p. 9-19.

ROONEY, op. cit., p. 30-37.

LITTRÉ, 1867, op. cit., p. 29.

LITTRÉ, E. La philosophie positive, tome I, n. 2, juillet-décembre, 1867b. p. 30.

DAMÁSIO, António. 0 erro de Descartes. São Paulo: Cia. das Letras, 2012; PORTUGAL, Francisco T.; FACCHINETTI, Cristiana (orgs.). História social da psicologia. Rio de Janeiro: NAU, 2018.

LEPENIES, op. cit., p. 11.

55 LITTRÉ, 1867a, op. cit. p. 38

LITTRÉ, op. cit., p. 26.

LITTRÉ, 1864, op. cit., p. 562.

LITTRÉ, 1867b, op. cit., p. 135.

Idem.

Idem, p. 145.

RODRIGUES, Francisco M. Marx no seu tempo. Lisboa: Dinossauro, 2001. p. 104-105

Este tema será explorado em outro artigo já em processo de elaboração.

HOBSBAWM, Eric J. História do marxismo, v. 2. Rio de Janeiro: Paz e Terra, 1982

LITTRÉ, 1867b, op. cit., p. 141-142.

LITTRÉ, E., La philosophie positive, tome XIV, n. 2, Paris, janvier-juin de 1875, p. 85.

LITTRÉ, 1875, op. cit., p. 90.

LITTRÉ, E. La philosophie positive, tome XXI, n. 1, juillet-décembre de 1878. p. 60.

LITTRÉ, 1867a, op. cit., p. 79.

RENAN, Ernest. La reforme intellectuele et morale de la France. Paris: Union Générale, 1967.

ALBERT, Hans. Tratado da razão crítica. Rio de Janeiro: Tempo Brasileiro, 1976; LÖWY, op. cit.

LITTRÉ, 1879, op. cit., p. 50.

Idem, p. 65.

CARO, op. cit., p. 90

CARO, op. cit., p. 48; LITTRÉ, 1879, op. cit., p. 92-94.

CARO, op. cit.; LITTRÉ, 1879, p. 96.

Ver a este respeito: LITTRÉ, E. De l'établissement de la troisième republique en la France. Paris: La Philosophie Positive, 1880.

WINOCK, op. cit., p. 659-660.

Idem, p. 661

MARX, K. Obras escolhidas, v. 2. Rio de Janeiro: Alfa-Ômega, 1983. p. 41-47.

CARO, op. cit., p. 50. 
81 GRANGE, op. cit., p. 113-114.

82 GRANGE, op. cit., p. 116.

83 OZOUF, Mona. L'École, L'Église et la République (1871-1914). Paris: Points, 1982.

84 CARO, op. cit., p. 90.

85 LITTRÉ, 1880, op. cit.

86 CARO, op. cit., p. 95.

87 CARO, op. cit., p. 145.

[Recebido em Dezembro de 2020. Aceito para publicação em Março de 2021] 